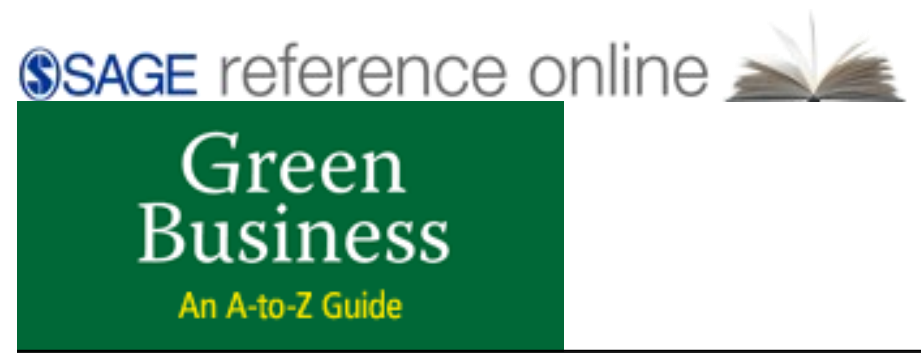

\title{
Global Sullivan Principles
}

The Global Sullivan Principles (GSP) arguably constitute the best-known template for addressing social responsibility within a business organization's governance documents, codes of conduct, and operating procedures. Based on the United Nations (UN) Universal Declaration of Human Rights, GSP promote the adoption of just and equitable policies for all affected by an organization's activities. They extend corporate responsibility beyond mere respect for the law to responsibility for community well-being, which is a key sustainability practice. GSP take their name from Leon $\mathrm{H}$. Sullivan, a civil rights leader who rose to international prominence by waging a campaign encouraging U.S. corporations operating in South Africa to stand in opposition to that country's oppressive racial policies.

Born in 1922 and raised in Charleston, South Carolina, Rev. Sullivan became pastor of Zion Baptist Church in Philadelphia in 1950. In 1964, he founded the Opportunities Industrialization Centers, a selfhelp training program that eventually spread to 76 centers in the United States, and 33 centers in 18 other countries. In 1971, Rev. Sullivan became the first African American member of the Board of Directors at General Motors. Early in his tenure, Rev. Sullivan pressured the corporation, then the single largest employer of blacks in South Africa, to place ethical and moral imperatives above the corporation's pecuniary interests. He urged GM to take a principled stand against South Africa's segregation laws, a system known as apartheid, by refusing to treat its black employees any differently than white ones. He had hoped to change the South African structure from within, but faced with an obdurate South African government and mounting public demand for governmentimposed economic sanctions, GM and more than 100 other multinational corporations (MNCs) ceased doing business in South Africa until after apartheid was dismantled in 1991.

Rev. Sullivan unveiled the GSP in November 1999 at a special meeting of the United Nations called by then Secretary-General Kofi Annan. The GSP were the culmination of a three-year collaboration between Rev. Sullivan and a group of concerned international business leaders. They saw the need for a set of transnationally valid ethical precepts to guide corporate behavior in a global economy that is not governed by the laws of any one nation, but is held accountable in the forum of world opinion by transnational nongovernmental organizations (NGOs) and an unrelenting international media that closely monitors MNC operations in less-developed nations (LDNs). The objectives of the Global Sullivan Principles are: 1 ) to show respect and support for human rights by treating employees, the communities where operations are conducted, and clients fairly and equitably; 2) to offer employees equal opportunities for improvement and advancement and refrain from exploiting vulnerable groups; 3) to respect employees' rights to freely associate; 4) to provide fair compensation to employees; 5) 
to safeguard workers' health and that of the community by engaging in sustainable development; 6) to act conscionably with respect to laws and intellectual property rights; 7 ) to positively contribute to communities where operating; and 8) to advocate the propagation of these principles.

The eight overarching principles point the way for companies to pursue their legitimate business objectives in the global marketplace while operating in a socially responsible manner. The Leon $\mathrm{H}$. Sullivan Foundation (LHSF) maintains a list of organizations that have made a commitment to operate under the GSP. Endorsing companies commit to upholding these standards in both their domestic and foreign operations. There is no fee for registering as a GSP endorser; a company simply completes the Endorser Registration Form online at the LHSF Website. Once registered, an endorser may display the Global Sullivan Principles Endorser Seal on its own Website and include it on letterhead, business cards, and other materials. LHSF requires each endorser to file an annual restatement of endorsement and a report on progress made toward achieving GSP-based goals. LHSF may remove an endorser if commitment to the GSP is not apparent in words or deeds.

The November 1999 introduction of the GSP was well timed, as there was growing public demand to impose a code of ethical conduct on business. That same month, mass demonstrations disrupted the World Trade Organization (WTO) meeting in Seattle, Washington-reactions emblematic of public disenchantment that had been growing for a number of years because of the increased reliance of American MNCs on moving operations offshore or outsourcing problematic operations to contractors in LDNs. The North American Free Trade Agreement (NAFTA) had been in effect for a decade, and critics charged that NAFTA gave U.S. manufacturers license to flee the restrictive laws of the United States for LDNs, where cheaper labor and lax environmental laws made operations more profitable. The GSP filled a void, and companies responded to public pressure to become endorsers.

The GSP are still relevant in 2010. Chevron and Shell face corporate dilemmas in their operations in Nigeria, not dissimilar from those companies that acquiesced to apartheid in South Africa. Amnesty International and environmental groups claim that the companies have caused significant environmental degradation of the Nigeria Delta region, and that they have not lived up to their human rights responsibilities, having allowed conditions of high unemployment and a lack of basic resources, such as fresh water and electricity, to persist.

\section{Environmental Sustainability and the GSP}

Many of the LDNs that attract outsourcing MNCs have no laws in place to protect the environment, which has caused transnational NGOs-an emerging global civil society-to view MNCs operating offshore plants with the hermeneutics of suspicion. Hence, it is not just coincidental that the GSP commit those endorsing its precepts to protect of the environment in Principle \#5, which addresses both protection of the human environment and promotion of sustainable development. Today, being a steward of the environment is integral to the notion of good corporate citizenship. Moreover, the international community is reaching a consensus about the universal applicability of certain sustainability guidelines; for example, the Ceres Principles, ISO 14000, GRI Sustainability Guidelines, and the UN Environmental Principles (UNEP). Each of these sustainability guidelines reflects uniformity of purpose, in terms of the environmental stewardship goals being advanced. 
The GSP encourage companies to manage their environmental performance as carefully as they manage quality, product/market development, and customer relationships. But unlike the environment-specific guidelines, GSP is not a science-based system, and provides no metrics against which to measure accomplishment. Some analysts feel that the lack of metrics in all areas poses a systemic problem of GSP. At the least, the applications of GSP, whether in South Africa, Nigeria, or elsewhere, show the need for independent scrutiny. Rev. Sullivan sought to establish external reporting requirements, as well as a system for monitoring an endorser's adherence to the GSP; however, he died in April 2001, prior to accomplishing this goal.

Gwendolyn Yvonne Alexis Monmouth University

\section{Further Readings}

Alexis, Gwendolyn Yvonne. "Coming Home to Roost: Offshore Operations from an In-House Perspective." In Controversies in International Corporate Responsibility , J. Hooker, ed. International Corporate Responsibility Series, Vol. 3. Pittsburgh, PA: Carnegie Mellon University, 2007.

Gentile, Carmen. "Analysis: Chevron Taking Hit in Nigeria." United Press International, 2007. http:// www.upi.com/Science News/Resource-Wars/2007/05/09/Analysis-Chevron-taking-hit-in-Nigeria/UPI26241178757663/(Accessed January 2010).

Sethi, S. Prakash Sethi and Oliver Williams. "Creating and Implementing Global Codes of Conduct: An Assessment of the Sullivan Principles as a Role Model for Developing International Codes of ConductLessons Learned and Unlearned." Business and Society Review vol. 105 no. 2 (2000).

Sullivan Foundation. "Global Sullivan Principles." www.thesullivanfoundation.org/gsp/default.asp (Accessed January 2010).

\section{Entry Citation:}

Alexis, Gwendolyn Yvonne. "Global Sullivan Principles." Green Business: An A-to-Z Guide. 2010. SAGE Publications. 7 Sep. 2010. <http://www.sage-ereference.com/greenbusiness/Article_n78.html>.

\section{(S)SAGE}

(C) SAGE Publications, Inc. 